\title{
Aplikasi Zeolite dari Cangkang Kelapa Sawit Pada Penyerapan Logam Kromium Heksavalen $\left(\mathrm{Cr}^{6+}\right)$ Heksavalen Pada Industri Elektroplating
}

\author{
Lince Muis*, Edwin Permana, Hasrul Anwar \\ Program Studi Teknik Kimia Fakultas Teknik Universitas Jambi \\ Jl. Tri Brata, Pd. Meja, Mestong, Kabupaten Muara Jambi, Jambi 36361 \\ *e-mail: ilincemuisismet@yahoo.com
}

\begin{abstract}
ABSTRAK
Zeolit merupakan senyawa alumino-silikat hidrat terhidrasi dengan unsur utama yang terdiri dari kation alkali dan alkali tanah terutama $\mathrm{Ca}, \mathrm{K}$ dan $\mathrm{Na}$, dengan rumus umum $\left(\mathrm{L}_{\mathrm{m}} \mathrm{Al}_{\mathrm{x}} \mathrm{Si}_{\mathrm{g}} \mathrm{O}_{2} \mathrm{nH}_{2} \mathrm{O}\right)$ dimana $\mathrm{L}$ adalah logam. Zeolit dapat disintesis dari suatu sampel dengan syarat mengandung senyawa silika dan alumina yang mengandung alkali hidroksida atau basa-basa organik didalamnya. Cangkang kelapa sawit merupakan salah satu limbah industri yang mengandung banyak mineral seperti $\mathrm{SiO} 258,02 \%$; Al2O3 8,7\%. Sumber silika dan alumina pada cangkang kelapa sawit digunakan sebagai bahan dasar pembuatan zeolit dengan menggunakan metode hidrotermal didalam sebuah reaktor. Sampel halus cangkang sawit dilebur dengan $\mathrm{NaOH}$ pada suhu $500^{\circ} \mathrm{C}$ selama 1 jam dan diencerkan untuk menghasilkan reaktan natrium silikat. Pembuatan reaktan natrium aluminat dilakukan dengan melarutkan $\mathrm{NaOH}$ dalam aquades kemudian dipanaskan dan ditambahkan $\mathrm{Al}(\mathrm{OH})_{3}$ kedalam larutan $\mathrm{NaOH}$ disertai pengadukan. Pembuatan zeolit dilakukan dengan cara mencampurkan reaktan natrium silikat dan natrium aluminat dan proses kristalisasi zeolit dilakukan menggunakan reaktor hidrotermal yang dipanaskan didalam oven dengan memvariasikan temperatur hidroternal $120^{\circ} \mathrm{C}, 150^{\circ} \mathrm{C}$ dan $180^{\circ} \mathrm{C}$ selama 8 jam. Zeolit hasil sintesis dikarakterisasi menggunakan XRF, FTIR dan SEM EDX.
\end{abstract}

Kata kunci: Cangkang kelapa sawit; Zeolit; Hidrotermal; Karakterisasi

\section{ABSTRACT}

Zeolite is a hydrated alumino-silicate compound having a main element which consists of alkali and alkaline-earth cations, especially $\mathrm{Ca}, \mathrm{K}$ and $\mathrm{Na}$, with a general formula ( $\mathrm{LmAlx} \mathrm{Sig} \mathrm{O}_{2} \mathrm{nH}_{2} \mathrm{O}$ ) where $\mathrm{L}$ is a metal. Zeolite can be synthesized from a sample containing silica and alumina. The compounds contain alkali hydroxide or organic bases. Palm kernel shells are one of the industrial wastes containing many minerals such as $\mathrm{SiO}_{2} 58.02 \% ; \mathrm{Al}_{2} \mathrm{O}_{3} 8.7 \%$. The source of silica and alumina in oil palm shells is used as a base for making zeolites using the hydrothermal method in a reactor. Fine samples of palm shells were melted with $\mathrm{NaOH}$ at $500^{\circ} \mathrm{nn} \mathrm{C}$ for 1 hour and diluted to produce sodium silicate reactants. Making sodium aluminate reactant is done by dissolving $\mathrm{NaOH}$ in distilled water and then heating and adding $\mathrm{Al}(\mathrm{OH})_{3}$ to $\mathrm{NaOH}$ solution with stirring. Making zeolite is done by mixing sodium silicate and sodium aluminate reactants and the zeolite crystallization process is carried out using a hydrothermal reactor heated in the oven by varying the hydroternal temperature of $1200 \mathrm{C}, 150^{\circ} \mathrm{C}$ and $1800 \mathrm{C}$ for 8 hours. The synthesized zeolite was characterized using XRF, FTIR and SEM EDX.

Keywords: Palm kernel shell; Zeolite; Hydrothermal; Characterization

\section{Pendahuluan}

Salah satu adsorben yang telah dimanfaatkan oleh peneliti untuk adsorben logam berat adalah cangkang kelapa sawit. Dengan memanfaatkan cangkang kelapa sawit sebagai adsorben, berarti juga menyelamatkan lingkungan dari pencemaran oleh limbah industri ini. Saat ini pemanfaatan cangkang belum digunakan secara maksimal. Salah satu penyebabnya, karena limbah jenis ini sangat sukar terdekomposisi secara alami. Salah satu teknologi alternatif yang dapat menjadi solusi bagi penanganan permasalahan limbah padat kelapa sawit ialah dengan teknik hidrotermal. Dengan teknik hidrotermal limbah padat kelapa sawit dapat diolah secara cepat untuk menghasilkan produk salah satunya zeolit.

Zeolit adalah senyawa alumino silikat dengan struktur rangka (frameworks) dan mempunyai pori (rongga) dan saluran yang diisi oleh kation dan molekl air yang dapat mudah dipertukarkan (exchangeable) sehingga dapat mengadsorpsi ion. Zeolit sebagai adsorben logam berat telah banyak dilakukan oleh peneliti sebelumnya. Beberapa zeolit yang telah diteliti antara lain adsorben logam berat $\mathrm{Pb}$ (II) (Woolard et al.,2000), logam berat ion Cadmium (Lucia et al.,2001), Logam berat Tembaga (II) (Ahmad et al.,2012) dan Logam berat Seng dan Tembaga (Wang et al.,2009). 
Berdasarkan paparan diatas maka penelitian ini akan dilakukan dengan mensintesis zeolit dari cangkang kelapa sawit sebagai adsorben logam kromium heksavalen $\left(\mathrm{Cr}^{6+}\right)$ pada industri elektroplating menggunakan metode reaktor hidrotermal.

\section{Metodologi Penelitian}

\subsection{Bahan Penelitian}

Cangkang sawit diambil dari penampungan cangkang kelapa sawit PT. PN VI. Sampel dicuci dahulu, lalu dikeringkan sambil diangin-anginkan kemudian dioven selanjutnya dilakukan pengabuan pada suhu $500^{\circ} \mathrm{C}$. Sampel kemudian dihaluskan dan diayak dengan ayakan 100 mesh sehingga diperoler serbuk halus cangkang kelapa sawit.

\subsection{Alat Penelitian}

Alat yang digunakan dalam penelitian ini erlenmeyer, gelas ukur, gelas kimia, corong pisah, cawan crussible, cawan alumunium, reaktor, oven, furnace, ayakan, grinder, neraca analit, Scanning Electron Microscopy, X-Ray Diffraction, Gas Cromatografy Mass Spectroscopy.

\subsection{Preparasi Sampel}

Serbuk cangkang kelapa sawit dikarakterisasi dengan menggunakan XRF untuk melihat kandungan Si dan Al yang menjadi penyusun utama zeolit. Sampel kemudian akan disintesis menjadi zeolit.

\subsection{Metode Analisis}

\section{Pembuatan Larutan Natrium Silikat}

Pembuatan larutan natrium silikat dilakukan dengan mencampur sebanyak 25 gram serbuk cangkang kelapa sawit dengan $\mathrm{NaOH}$ sebanyak 62,5 gram $(1: 2,5)$ kemudian difurnace pada temperatur $600^{\circ} \mathrm{C}$ selama 1 jam. Hasil kemudian dilarutkan dengan aquades secukupnya dan didiamkan selama 24 jam. Larutan selanjutnya disaring dan filtrat diencerkan sampai volume $250 \mathrm{~mL}$ dan dilakukan analisa FTIR (Fajril,2012).

\section{Pembuatan Reaktan Natrium Aluminat}

Pembuatan reaktan Natrium Aluminat dilakukan dengan melarutkan 30,5 gram $\mathrm{NaOH}$ dalam $100 \mathrm{~mL}$ aquades kemudian dipanaskan dan ditambahkan 21,65 gram $\mathrm{Al}(\mathrm{OH})_{3}$ kedalam larutan $\mathrm{NaOH}$ disertai pengadukan. Larutan diencerkan hingga $250 \mathrm{~mL}$ dan dilakukan analisa FTIR (Fajril, 2012).

\section{Pembuatan dan Karakterisasi Zeolit dari Cangkang Kelapa Sawit}

Pembuatan zeolit dilakukan dengan mereaksikan 60 $\mathrm{mL}$ natrium silikat dengan $40 \mathrm{~mL}$ natrium aluminat dengan disertai pengadukan selama 3 jam. Campuran dimasukkan kedalam reaktor hidrotermal dan dilakukan proses kristalisasi pada $120^{\circ} \mathrm{C}, 150^{\circ} \mathrm{C}$ dan $180^{\circ} \mathrm{C}$ selama 8 jam. Padatan hasil kristalisasi dicuci hingga filtrat bening dan padatan dikeringkan pada suhu $80^{\circ} \mathrm{C}$ selama 4 jam. Padatan yang diperoleh selanjutnya dikarakterisasi menggunakan XRF dan SEM.
Proses Adsorpsi Zeolit Terhadap Kromium Heksavalen $\left(\mathrm{Cr}^{6+}\right)$ dengan Pengaruh Variasi Waktu Kontak

Proses adsorpsi dilakukan dengan metode batch. Proses adsorpsi dimulai dengan menambahkan $50 \mathrm{~mL}$ larutan yang mengandung logam kromium heksavalen $\left(\mathrm{Cr}^{6+}\right)$ dengan konsentrasi awal $25 \mathrm{ppb}$ ke dalam beaker glass kemudian ditambahkan $1 \mathrm{~g}$ zeolit sintesis. Kemudian diaduk dengan magnetik stirer pada kecepatan $80 \mathrm{rpm}$ (Ahmad,2012) dan diambil sampel pada menit ke- 30, 60, 90, 120, 150 dan 180. Kemudian dilakukan pengujian dengan AAS untuk mengetahui konentrasi yang tersisa. Maka akan diperoleh waktu kontak optimum dan terbentuk kurva pengaruh variasi waktu terhadap logam yang terserap.

\section{Hasil dan Pembahasan}

\subsection{Karakterisasi Zeolit}

Karakterisasi Zeolit dengan X-Ray Fluoresence (XRF)

$\mathrm{XRF}$ merupakan instrumen analisis sinar $\mathrm{X}$ dengan metode non destruktif yang digunakan untuk mengidentifikasi serta menentukan konsentrasi elemen yang ada pada padatan, bubuk maupun cairan dan mampu mengukur elemen dari berilium (Be) hingga Uranium. Komposisi sampel hasil analisa dapat di lihat dari konsentrasi (ppm) dan juga massa (\%). Hasil XRF untuk zeolit pada temperatur $120^{\circ} \mathrm{C}, 150^{\circ} \mathrm{C}$ dan $180^{\circ} \mathrm{C}$ dapat dilihat pada Tabel 1 .

Tabel 1. Analisa XRF pada Zeolit $120^{\circ} \mathrm{C}, 150^{\circ} \mathrm{C}$ dan $180^{\circ} \mathrm{C}$.

\begin{tabular}{lccc}
\hline \multirow{3}{*}{ Unsur } & \multicolumn{3}{c}{ Hasil Analisa } \\
\cline { 2 - 4 } & $120^{\circ} \mathrm{C}(\%)$ & $150^{\circ} \mathrm{C}(\%)$ & $180^{\circ} \mathrm{C}(\%)$ \\
\hline $\mathrm{Si}$ & 8,94 & 13,3 & 10,7 \\
$\mathrm{Al}$ & 9,11 & 14,3 & 23,3 \\
$\mathrm{Na}$ & 31,4 & 41,4 & 59,0 \\
$\mathrm{Rasio}$ & 1,01 & 1,09 & 3,32 \\
$\mathrm{Si} / \mathrm{Al}$ & & & \\
\hline
\end{tabular}

Zeolit sintesis dapat diklasifikan menjadi 3 jenis berdasarkan rasio $\mathrm{Si} / \mathrm{Al}$, zeolit kategori rendah rasio $\mathrm{Si} / \mathrm{Al}$ nya $1-1,5$ contohnya zeolit $\mathrm{A}, \mathrm{X}$. Zeolit kategori sedang rasio Si/Al nya 1,5-5, contohnya zeolit Erionite, Chabazite, Chlinoptilolite. Dan kategori tinggi rasio Si/Al nya 10-100 contohnya silikalit dan ZSM-5 ( Payra et al. 2003). Perbandingan Si dan Al dari zeolit hasil sintesis menggambarkan fungsi kapasitas tukar kationnya. Hasil analisis XRF menunjukkan bahwa perbandingan persentase antara $\mathrm{Si}$ dan $\mathrm{Al}$ relatif kecil. Pada suhu $120^{\circ} \mathrm{C}$ persentase konsentrasi Si sebesar 8,94 $\%$ dan $\mathrm{Al}$ sebesar $9,11 \%$ sehingga didapat rasio $\mathrm{Si} / \mathrm{Al}$ nya sebesar 1,01 . Pada hasil zeolit sintesis suhu $150^{\circ} \mathrm{C}$ diketahui persentase konsentrasi Si sebesar 13,3\% dan $\mathrm{Al}$ sebesar 14,3\% sehingga didapat rasio $\mathrm{Si} / \mathrm{Al}$ nya sebesar 1,07. Berdasarkan rasio perbandingan $\mathrm{Si} / \mathrm{Al}$ zeolit sintesis suhu $120^{\circ} \mathrm{C}$ dan $150^{\circ} \mathrm{C}$ termasuk kedalam zeolit yang kategori rendah ( zeolit A,X). Sedangkan pada zeolit sintesis suhu $180^{\circ} \mathrm{C}$ diketahui konsentrasi Si sebesar 10,7 dan $\mathrm{Al}$ sebesar 23,3 sehingga didapat rasio 
Si/Al nya sebesar 3,32 sehingga zeolit ini termasuk kedalam kategori sedang (1,5-5).

Kelemahan dari analisa XRF ini tidak dapatnya menentukan struktur kristal pada zeolit hasil sintesis, maka untuk menentukan kristal yang terbentuk, akan dilakukan analisa XRD sehingga dapat diketahui jenis zeolit yang terbentuk dan kristalinitas zeolit mana yang terbaik.

\section{Karaktesisasi Zeolit sintesis suhu $120^{\circ} \mathrm{C}, 150^{\circ} \mathrm{C}$ dan $180^{\circ} \mathrm{C}$ dengan $X$-Ray Diffraction (XRD)}

Setelah diketahui rasio $\mathrm{Si} / \mathrm{Al}$ pada zeolit hasil sintesis $120^{\circ} \mathrm{C}, 150^{\circ} \mathrm{C}$, dan $180^{\circ} \mathrm{C}$ sehingga untuk membuktikan jenis zeolit yang terbentuk dilakukan analisa menggunakan X-Ray Diffraction (XRD) yang merupakan metode analisis kualitatif yang memberikan informasi mengenai struktur kristal suatu mineral tertentu. Kristalinitas sampel dilihat dari pola difaktogramnya. Difaktogram yang memiliki pemisahan puncak-puncak yang jelas dan intensitas ketajaman puncaknya tinggi memiliki kristalinitas yang baik. Hasil XRD untuk zeolit pada temperatur $120^{\circ} \mathrm{C}, 150^{\circ} \mathrm{C}$, dan $180^{\circ} \mathrm{C}$ dapat dilihat pada Gambar 1.

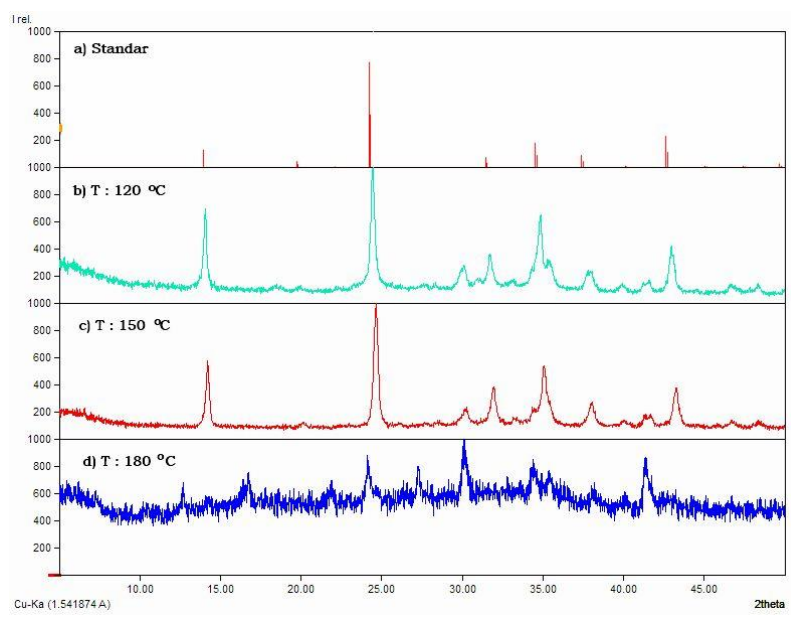

Gambar 1. Hasil XRD untuk zeolit pada temperatur (a) $120^{\circ} \mathrm{C}$, (b) $150^{\circ} \mathrm{C}$, dan (c) $180^{\circ} \mathrm{C}$ dan Standar JCPDS.

Dari Gambar 1 diketahui bahwa perbedaan temperatur memberikan hasil difaktogram berbeda dengan intensitas puncak yang berbeda pula. Pada temperatur $120^{\circ} \mathrm{C}$ terdapat 12 puncak (peak), $150^{\circ} \mathrm{C}$ terdapat 8 puncak dan $80^{\circ} \mathrm{C}$ terdapat 7 puncak pada $2 \theta$. Tabel 2 posisi sudut $2 \theta$ untuk zeolit hasil sintesis :

Fasa zeolit yang terbentuk pada Tabel 3 menunjukkan bahwa pada temperatur $120^{\circ} \mathrm{C}$ merupakan fasa zeolit campuran yaitu Zeolit A, Sodalit dan Faujasit. Zeolit tipe A di klasifikasikan dalam 3 jenis berbeda yaitu 4A, 5A dan 6A proses dan komponen utama sama hanya berbeda jenis kation. Zeolit 4A memiliki rumus molekul $\mathrm{Na}_{12}\left[\left(\mathrm{~A}_{10}\right)\left(\mathrm{SiO}_{2}\right)\right]_{12} .27 \mathrm{H}_{2} \mathrm{O}$ dengan struktur kristal simetri kubik (Fajri et al, 2012). Dari Tabel 3 menunjukkan nilai $2 \theta=31.73,39.91$ $41.64,46.71,48.37$ pada suhu $120^{\circ} \mathrm{C}$ yang menjadikan hasil zeolit $4 \mathrm{~A}$ yang terbentuk tidak jauh berbeda dengan zeolit 4A standar dan literatur penelitian sebelumnya.
Tabel 2. Posisi sudut $2 \theta$ zeolit $120^{\circ}, 150^{\circ} \mathrm{C}, 180^{\circ} \mathrm{C}$

\begin{tabular}{|c|c|c|c|}
\hline No. & $\begin{array}{c}\text { Zeolit } \\
\text { T:120 } 10^{\circ} \mathrm{C} \\
\left.\text { (Pos. }\left[{ }^{\circ} 2 \mathrm{Th} .\right]\right)\end{array}$ & $\begin{array}{c}\text { Zeolit } \\
\text { T: } 150^{\circ} \mathrm{C} \\
\left.\text { (Pos. }\left[{ }^{\circ} 2 \mathrm{Th} .\right]\right)\end{array}$ & $\begin{array}{c}\text { Zeolit } \\
\text { T: } 180^{\circ} \mathrm{C} \\
\left.\text { (Pos. }\left[{ }^{\circ} 2 \mathrm{Th} .\right]\right)\end{array}$ \\
\hline 1 & 14.09 & 14.22 & 12.74 \\
\hline 2 & 24.41 & 24.66 & 16.76 \\
\hline 3 & 30.18 & 30.30 & 24.12 \\
\hline 4 & 31.73 & 31.97 & 27.25 \\
\hline 5 & 34.84 & 35.08 & 30.10 \\
\hline 6 & 35.43 & 38.08 & 34.37 \\
\hline 7 & 37.74 & 41.70 & 41.30 \\
\hline 8 & 39.91 & 43.30 & \\
\hline 9 & 41.64 & & \\
\hline 10 & 42.95 & & \\
\hline 11 & 46.71 & & \\
\hline 12 & 48.37 & & \\
\hline
\end{tabular}

Tabel 3. Fasa yang terbentuk dari padatan hasil sintesis

\begin{tabular}{|c|c|c|c|c|}
\hline Sampel & $\begin{array}{c}\text { Zeolit A } \\
\text { (Pos. } \\
\text { ['2Th.]) }\end{array}$ & $\begin{array}{l}\text { Sodalit } \\
\text { (Pos. } \\
\left.\left[{ }^{\circ} 2 \mathrm{Th} .\right]\right)\end{array}$ & $\begin{array}{c}\text { Faujasit } \\
\text { (Pos. } \\
\left.\left[{ }^{\circ} 2 \mathrm{Th} .\right]\right)\end{array}$ & Produk \\
\hline $120^{\circ} \mathrm{C}$ & $\begin{array}{l}31.73, \\
39.91 \\
41.64, \\
46.71 \\
48.37\end{array}$ & $\begin{array}{l}14.09, \\
24.41, \\
34.84, \\
35.43, \\
37.74, \\
42.95\end{array}$ & 30.18 & $\begin{array}{l}\text { Zeolit } \\
\text { A, } \\
\text { Sodalit, } \\
\text { Faujasit }\end{array}$ \\
\hline $150^{\circ} \mathrm{C}$ & - & $\begin{array}{l}14.22, \\
24.66 \\
35.08, \\
38.08, \\
43.30\end{array}$ & - & Sodalit \\
\hline $180^{\circ} \mathrm{C}$ & - & $\begin{array}{l}24.12 \\
34.37 \\
41.30\end{array}$ & - & Sodalit \\
\hline Standar & $\begin{array}{l}10.15, \\
12.45, \\
16.09, \\
21.64, \\
23.96, \\
27.08, \\
29.91, \\
34.15 \\
\text { (ASTM } \\
\text { no. 39- } \\
222 \text { ) }\end{array}$ & $\begin{array}{l}14.06, \\
19.94, \\
22.30, \\
24.48, \\
28.33, \\
31.77, \\
34.89, \\
37.78, \\
41.53, \\
42.66, \\
44.16, \\
47.34\end{array}$ & $\begin{array}{l}10.11, \\
11.86, \\
15.60, \\
20.27, \\
27.70, \\
30.62, \\
32.32, \\
34.50 \\
\text { (Breck, } \\
1974)\end{array}$ & \\
\hline
\end{tabular}

Jenis zeolit yang lain yang muncul pada temperatur $120^{\circ} \mathrm{C}$ adalah Sodalit terdapat 6 puncak pada $2 \theta$ yang menunjukkan puncak Sodalit. Pada Gambar 1(c) menunjukkan hasil yang di peroleh pada temperatur $150^{\circ} \mathrm{C}$ terdapat 6 puncak utama dengan intensitas yang baik dan sesuai dengan standar. Enam puncak yang muncul pada $2 \theta=31.73,39.91,41.64,46.71,48.37$ terindentifikasi merupakan puncak yang dimiliki Sodalit dengan intensitas yang semakin bertambah. Sedangkan untuk zeolit $4 \mathrm{~A}$ dan Faujasit tidak teridentifikasi lagi pada temperatur $150^{\circ} \mathrm{C}$ dari hasil analisa XRD karena tidak adanya puncak dari zeolit 4A dan Faujasit. Menurut Treacy (2001), Sodalit muncul 
pada $2 \theta=13,93^{\circ} ; 24,26^{\circ} ; 31,55^{\circ} ; 32,53^{\circ} ; 34,61^{\circ} ; 37,44^{\circ}$; $41,53^{\circ} ; 42,66^{\circ} ; 44,16^{\circ} ; 47,34^{\circ}$, untuk Faujasit muncul pada $2 \theta=30,18^{\circ}$ yang merupakan kerangka dari zeolit $\mathrm{X}$.

Zeolit 4A dan Faujasit merupakan zeolit yang tersusun oleh cage Sodalit yang saling berikatan pada cincin ganda D4R dan D6R. Tidak terbentuknya zeolit $4 \mathrm{~A}$ dan Faujasit pada $150^{\circ} \mathrm{C}$ dapat di indikasikan bahwa zeolit $4 \mathrm{~A}$ dan Faujasit yang terbentuk pada $120^{\circ} \mathrm{C}$ masih dalam keadaan kurang stabil sehingga fasa dari zeolit $4 \mathrm{~A}$ dan Faujasit larut pada suhu $150^{\circ} \mathrm{C}$. Adanya pergantian fasa ini dikenal dengan transformasi fasa yaitu fasa yang tidak stabil akan digantikan oleh fasa yang lebih stabil (Barrer, 1982).

Dari gambar 1(c) hasil dicocokkan dengan JCPDS (Joint Committe on Powder Diffraction Standards) dari Treacy (2001) dan Alim (2015) dan Standar sodalit MATCH pada Gambar 14 diketahui bahwa Sodalit hasil sintesis pada temperatur $150^{\circ} \mathrm{C}$ memiliki puncak karakteristik yang sama. Berdasarkan literatur karakteristik Sodalit dilihat dari 3 puncak utama yang terbentuk pada $2 \theta 14.22^{\circ}, 24.66^{\circ}, 31.97^{\circ}$ (Gambar 2). Menurut Widiawati (2005) puncak karakteristik Sodalit berada pada $2 \theta 14,0^{\circ} ; 24,56^{\circ} ; 31,87^{\circ}$. Sodalit memiliki rumus kimia $\mathrm{Na}_{6}\left[\mathrm{AlO}_{4} \mathrm{SiO}_{4}\right]_{6} .8 \mathrm{H}_{2} \mathrm{O}$ dengan sistem kristal kubik.

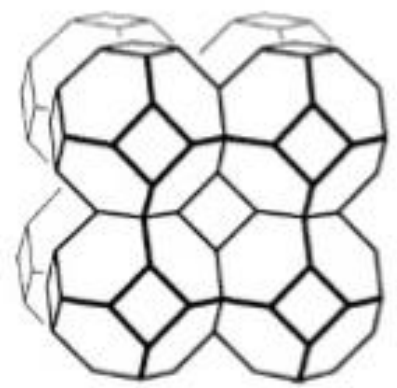

Gambar 2. Struktur Kristal Sodalit

Unit Sodalit ( $\beta$ cage) terdiri dari cincin 6 atau cincin 4 yang bergabung bersama membentuk kuboktahedron (oktahedral terpancung). Masing-masing Sodalit cage terdiri dari 26 rantai tetrahedral. Apabila Sodalit cage dihubungkan melalui cincin ganda empat maka akan terbentuk zeolit A, tetapi apabila dihubungkan melalui cincin ganda enam maka terbentuk zeolit $\mathrm{X}$ dan zeolit Y. Ini menghasilkan bentuk cage yang lebih luas terdiridari 26 unit tetrahedral (Hamdan,1994).

Tabel 4. Perbandingan nilai $2 \theta$ Zeolit Sodalit

\begin{tabular}{|c|c|c|}
\hline $\begin{array}{c}\text { Sodalit } \\
\mathrm{T}: 150^{\circ} \mathrm{C}\end{array}$ & $\begin{array}{c}\text { Widiawati } \\
\text { (2005) }\end{array}$ & $\begin{array}{l}\text { Treacy } \\
(2001)\end{array}$ \\
\hline $14,22^{\circ}$ & $14,0^{\circ}$ & $14,26^{\circ}$ \\
\hline $24,66^{\circ}$ & $19,71^{\circ}$ & $20,07^{\circ}$ \\
\hline $30,30^{\circ}$ & $24,56^{\circ}$ & $24,65^{\circ}$ \\
\hline $31,97^{\circ}$ & $31,87^{\circ}$ & $31,99^{\circ}$ \\
\hline $35,08^{\circ}$ & $34,47^{\circ}$ & $34,87^{\circ}$ \\
\hline $38,08^{\circ}$ & $35,01^{\circ}$ & $35,13^{\circ}$ \\
\hline $41,70^{\circ}$ & $37,92^{\circ}$ & $38,05^{\circ}$ \\
\hline $43,30^{\circ}$ & $43,23^{\circ}$ & 43,39 \\
\hline
\end{tabular}

Dari Tabel 4, bahwa nilai untuk Sodalit hasil sintesis pada $\mathrm{T}: 150^{\circ} \mathrm{C}$ dan nilai $\mathrm{d}[\AA ̊ \mathrm{~A}]$ tidak jauh berbeda dengan nilai $2 \theta$ Treacy (2001) dan Widiawati (2005).

Temperatur sangat berpengaruh pada proses preparasi karena atom-atom tidak bergerak pada temperatur $0 \mathrm{~K}$. Pada temperatur yang sangat tinggi, kristal dapat tumbuh dengan sangat cepat. Bila temperatur dinaikkan maka energinya akan meningkat sehingga akan menyebabkan atom-atom bergetar dan menimbulkan jarak antar atom yang lebih besar. Jarak antar atom yang lebih besar akan memungkinkan atomatom yang memiliki energi tinggi atau berada di atas energi ikatannya akan bergerak mendobrak ikatannya dan melompat ke posisi yang baru dan akan mengakibatkan jumlah kekosongan meningkat dengan cepat. Pada suhu tinggi memungkinkan atom-atom asing menyusup lebih dalam diantara celah-celah atom. Hal ini akan menyebabkan atom-atom asing terikat dan semakin kuat menempel pada bahan, sehingga kristal yang terbentuk akan memiliki karakteristik yang baik (Van Vlack, 2004).

Apabila dalam kristal masih terdapat fasa amorf jika gel amorf sisa larut kembali maka akan terjadi pertumbuhan kristal dan embrio inti tersebut sampai gel amorf sisa tersebut habis dan terbentuk kristal dalam keadaan stabil. (Hadi, 1986). Adanya kenaikan temperatur dapat menyebabkan struktur kristal berubah. Hidayati dan Muasyaroh (2008) menyatakan bahwa temperatur yang terlalu tinggi dengan waktu reaksi yang terlalu lama akan melarutkan fasa zeolit yang terbentuk. Konsentrasi Natrium dalam fasa larutan yang terlalu tinggi akan mengubah zeolit A ke bentuk zeolit Hidroksisodalit (Chang dan Shih, 2000). Sehingga pada temperatur $150^{\circ} \mathrm{C}$ tidak terdapat lagi zeolit campuran dan hanya terbentuk Sodalit.

Untuk gambar 1(d) menunjukkan hasil yang diperoleh pada temperatur $180^{\circ} \mathrm{C}$ teridentifikasi 7 puncak pada $2 \theta=12.74^{\circ}, 16.76^{\circ}, 24.12^{\circ}, 27.25^{\circ}, 30.10^{\circ}$, $34.37^{\circ}, 41.30$ dengan 3 puncak pada $2 \theta=24.12,34.37$, 41.30 masih puncak yang dimiliki Sodalit, tetapi dengan intensitas yang semakin menurun serta tingkat kekristalannya kurang baik di karenakan masih terdapat hump (struktur amorf). Struktur amorf terbentuk di sebabkan oleh terjadinya proses pendinginan yang terlalu cepat dan ini menyebabkan struktur partikel tidak teratur. Kristalisasi zeolit sintesis dipengaruhi beberapa faktor di antaranya temperatur kristalisasi. Dari gambar 1 dapat dilihat bahwa kenaikan temperatur dari $120^{\circ} \mathrm{C}$ ke $150^{\circ} \mathrm{C}$ menghasilkan tingkat kristalinitas yang semakin baik dan juga kemurnian zeolit yang diperoleh semakin baik karena tidak terbentuk lagi zeolit campuran. Untuk temperatur $180^{\circ} \mathrm{C}$ penurunan puncak difaktogram Sodalit mungkin dapat disebabkan pada saat proses hidrotermal berlangsung dimana penutup reaktor yang kurang rapat sehingga terjadi kebocoran dimana tekanan didalam reaktor berubah dan air menguap keluar karena temperatur hidrotermal yang digunakan cukup tinggi. Sehingga produk hidrotermal yang dihasilkan pada temperatur $180^{\circ} \mathrm{C}$ tidak berwarna putih tetapi berwarna coklat. Hal ini mengindikasikan bahwa struktur kristal Sodalit telah mengalami kerusakan sehingga intensitas puncaknya menurun dan pembentukan Sodalit tidak terjadi secara optimal. 
Dalam Zeolit intensitas puncak dari sudut kecil tergantung pada kandungan air antar kristal, sehingga intensitasnya akan menurun dengan adanya dehidrasi (Attkins, 1999).

Menurut Jumaeri (2008) pada dasarnya kenaikan temperatur tidak menimbulkan perubahan $2 \theta$ yang signifikan sehingga hal ini bukan merupakan karakteristik zeolit yang di inginkan. Tetapi akibat adanya kenaikan temperatur menimbulkan bertambah atau meningkatnya intensitas.

Zeolit yang dihasilkan pada penelitan ini pada kondisi temperatur hidrotermal $150^{\circ} \mathrm{C}$ mempunyai tingkat kristalinitas lebih baik dibandingkan dengan kristalinitas pada temperatur hidrotermal $120^{\circ} \mathrm{C}$. Penelitian sebelumnya yang dilakukan oleh Mimura et al (2001) temperatur hidrotermal yang lebih tinggi maka akan diperoleh produk hidrotermal memiliki kristalinias lebih baik. Zeolit murni dengan kristalinitas tinggi akan menghasilkan puncak sempit yang sangat jelas dengan garis dasar yang rendah dan datar (Attkins, 1999).

\section{Karakterisasi Zeolit dengan Scanning Electron Microscope (SEM)}

Analisis menggunakan SEM bertujuan untuk melihat morfologi bentuk partikel pada permukaan. Pada prinsipnya analisis permukaan melibatkan radiasi permukaan dengan sumber energi yang cukup untuk menembus dan menimbulkan emisi dari permukaan berkas energi yang bisa dianalis. Berikut hasil analisa SEM untuk Sodalit pada temperatur $150^{\circ} \mathrm{C}$.
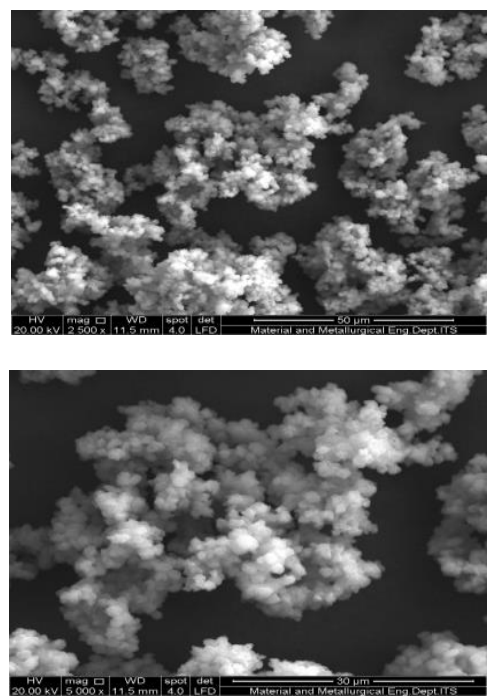

Gambar 3. Hasil SEM Sodalit perbesaran $30,0 \mu \mathrm{m}$ $(2500 x), 20,0 \mu \mathrm{m}(5000 \mathrm{x})$

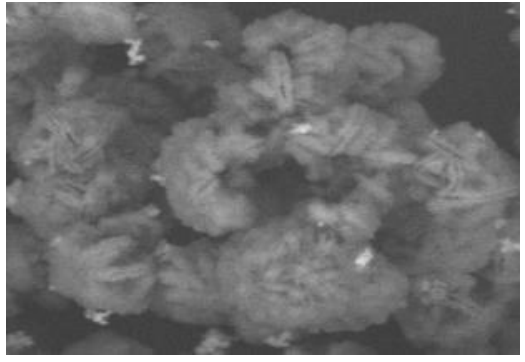

a

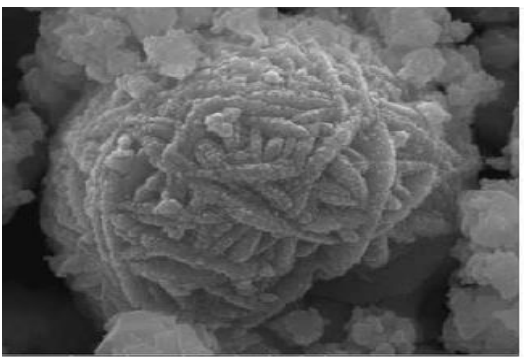

b

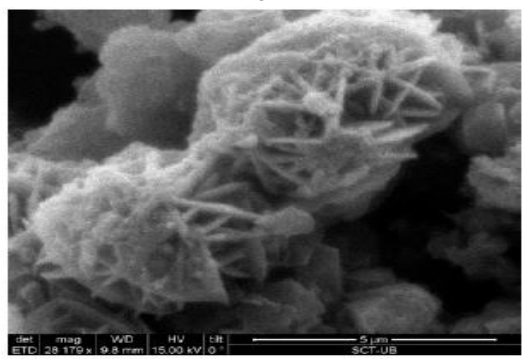

Gambar 4. (a) Sodalit $\mathrm{T}: 150^{\circ} \mathrm{C}$, (b) Sodalit (Fajar,2012) dan (c) Sodalit (Daniela et al, 2010)

Dari hasil analisa SEM gambar 4(a), Sodalit memiliki kemiripan bentuk yang sama dengan hasil penelitian (Fajar et al, 2012) gambar 4(b) dan penelitian (Daniela et al, 2010) gambar 4(c). Kristal berbentuk kubus dengan ukuran kecil dan halus serta memanjang yang saling berikatan merupakan bentuk kristal dari Sodalit. Kubus dengan ukuran kecil yang saling berikatan membentuk geometri memanjang lebih dominan jika dibandingkan dengan kubus yang berukuran lebih besar. Dari morfologi hasil SEM memperlihatkan adanya pori-pori yang terbentuk pada setiap kristal Sodalit (Wajima, 2005). Gambar 4 membuktikan bahwa salah satu sifat atau karakteristik zeolit adalah berpori karena kristal zeolit merupakan kerangka yang terbentuk dari jaring tetrahedral $\mathrm{SiO}_{4}$ dan $\mathrm{AlO}_{4}$ (Lobo et al, 2001). Hasil SEM juga memperlihatkan bentuk kristal yang seragam dan tidak terdapat bentuk kristal yang lain. Hal ini menunjukkan bahwa pada hasil hidrotermal dengan temperatur $150^{\circ} \mathrm{C}$, temperatur terbaik zeolit terbentuk paling banyak dan tidak ada campuran dari zeolit lain adalah Sodalit.

\section{Kesimpulan}

1. Pembuatan zeolit dari cangkang kelapa sawit dilakukan dengan melebur abu cangkang kelapa sawit dengan basa $\mathrm{NaOH}$ diperoleh Natrium 
Silikat dan direaksikan dengan Natrium Aluminat dengan menggunakan reaktor hidrotermal.

2. Variasi temperatur hidrotermal menghasilkan jenis zeolit berbeda dengan tingkat kristalinitas yang berbeda. Pada $\mathrm{T}=120^{\circ} \mathrm{C}$ menghasilkan zeolit campuran yaitu 4A, Sodalit dan Faujasit, pada $\mathrm{T}=150^{\circ} \mathrm{C}$ menghasilkan Sodalit dan pada $\mathrm{T}=180^{\circ} \mathrm{C}$ lebih cenderung amorf.

3. Ion logam $\mathrm{Cr} 3+$ yang terserap terjadi pada suhu $150^{\circ} \mathrm{C}$.

\section{Daftar Pustaka}

Agustinus, Eko, T.S. (2009). Sintesis Hidrotermal Atapulgit Berbasis Batuan Gelas Volkanik (Perlit): Perbedaan Perlakuan Statis Dan Dinamis Pengaruhnya Terhadap Kuantitas Dan Kualitas Kristal. Puslit Geoteknologi Komplek LIPI, Bandung

Belviso C., Belviso, C., Cavalcante, F., Lettino, A., dan Fiore, S. (2009). Zeolite Synthesised from Fused Coal Fly Ash at Low Temperature Using Seawater for Crystallization. ISSN 1946-0198.

Danny, Z.H. (2010). Tinjauan Terhadap Tailing Mengandung Unsur Pencemar Arsen (As), Merkuri (Hg), Timbal $(\mathrm{Pb})$ dan Kadmium (Cd) dari Sisa Pengolahan Bijih Logam. Jurnal geologi Indonesia, Vol. 1 No. 1, 31-36.

Graille, J., Lozano, P., Pioch, D. \& Geneste, P. 1985. Essais d'alcoolyse d'huiles Vegetales avec des Catalyseurs Naturels Pour la Production de Carburants Diesel. Oleagineux. 40(5): 271-276

Milton, R. 1989. Molecular sieve science and technology. ACS Symposium Series. Washington DC: American Chemical Society.

Suardana, I.N. 2003. Optimalisasi daya adsorpsi zeolit terhadap ion Chrom (III). Jurnal penelitian dan Pengembangan Sains dan Humaniora 2(1), 1733

Ulfah, M.E., Yasnur, F.A. dan Istadi. (2006). Katalis Zeolit $\mathrm{X}$ dari Tawas, $\mathrm{NaOH}$ dan Water Glass dengan ResponseSurface Methodology. Bulletin of Chemical Reaction Engineering \& Catalysis. 